Matthias Mehling, MD

Dominik Eichin, MSc

Patricia Hafner, MD

Gideon Hönger, BSc

Ludwig Kappos, MD*

Christoph Hess, MD, $\mathrm{PhD*}$

Neurol Neuroimmunol Neuroinflammation

2014;1:e28; doi: 10.1212/

NXI.0000000000000028

\section{AVIDITY OF VACCINE-INDUCED INFLUENZA IgG FAILS TO INCREASE IN FINGOLIMOD-TREATED PATIENTS WITH MS \\ OPEN}

Fingolimod—an efficacious compound for the treatment of relapsing multiple sclerosis (MS) - functionally antagonizes the S1P receptor. ${ }^{1-3}$ This antagonism inhibits egress of $\mathrm{T}$ cells from secondary lymphoid tissues, ${ }^{2}$ affects $\mathrm{B}$ cell migration, and functionally affects germinal center reactions. ${ }^{4}$

Although vaccine-specific antibodies can be induced in patients with MS under fingolimod therapy, ${ }^{5}$ the magnitude of such responses is reduced. ${ }^{6}$ It is unknown whether the quality of a vaccine-specific response, reflected for example in the avidity of induced antibodies, is affected by fingolimod.

Here, in a prospective open-label study that was approved by the institutional review board, we assessed the avidity of the immunoglobulin (Ig) $G$ response targeting influenza $\mathrm{A}$ and $\mathrm{B}$ before and after influenza vaccination. Avidity was compared between patients with MS treated with fingolimod and interferon- $\beta$ (IFN- $\beta$ ), as well as in a group of healthy controls (HC). All study participants gave written informed consent before entering the study. Patients had to fulfill the following inclusion criteria: definite relapsing MS, treatment with fingolimod $(0.5 \mathrm{mg} /$ day $)$ or with IFN- $\beta$, and age $\geq 18$ and $\leq 65$ years. HC had to fulfill the following inclusion criteria: absence of apparent acute or chronic disease and age $\geq 18$ and $\leq 65$ years. Exclusion criteria for all study participants were known hypersensitivity to influenza vaccine, influenza vaccination during the 180 days before entering the study, therapy with Igs or blood products during the 90 days before entering the study, treatment with steroids or immunomodulators (other than IFN- $\beta$ or fingolimod), and pregnancy. The primary research question was assessment of a vaccine-induced increase in the avidity of anti-influenza antibodies following influenza vaccination.

Characteristics of the study population were as follows. Patients treated with fingolimod: $\mathrm{n}=10$ (6 female/4 male), mean age 44.7 years, mean disease duration 11.2 years, mean Expanded Disability Status Scale (EDSS) score 2.6, mean duration of fingolimod treatment 2.9 years. Patients treated with IFN- $\beta: \mathrm{n}=10$ (8 female/2 male), mean age 40.8 years, mean disease duration 5.9 years, mean EDSS score 2.0, mean duration of IFN- $\beta$ treatment 3.6 years. HC: $\mathrm{n}=15$ (7 female/ 8 male), mean age 36.1 years. Blood samples were obtained before vaccination and 7, 14, and 28 days after vaccination (Mutagrip; Sanofi Pasteur SA, Lyon, France; year adjusted for 2009/2010).

The avidity of influenza-specific antibodies was determined by comparing binding of influenza-specific $\operatorname{IgG}$ in buffered saline vs binding after incubation in $6 \mathrm{M}$ urea (10 minutes) using a quantitative ELISA system, as previously described (Genzyme Virotech, Ruesselsheim, Germany). 5,7 Thus, obtained avidity index data were distributed normally (Shapiro-Wilk test) and statistically analyzed by 2 -sided Student $t$ test. $p$ values $<0.05$ were considered statistically significant.

Prior to vaccination, avidity of $\operatorname{IgG}$ specific for influenza $A$ and $B$ was similar in all study groups (figure, $A$ and $B$ ). Following vaccination, the avidity of $\operatorname{IgG}$ targeting influenza $A$ and $B$ significantly and similarly increased in patients treated with IFN- $\beta$ and in HC (figure, $A$ and B). In contrast, among individuals treated with fingolimod, no significant vaccine-induced increase in the avidity of influenza-specific IgG, against both type A and B, was detected (figure, A and B). Vaccination was tolerated comparably well in all study groups.

These data demonstrate that patients with MS treated with fingolimod significantly differ from $\mathrm{HC}$ and patients with MS treated with IFN- $\beta$ in that they fail to increase avidity of influenza-specific IgG following vaccination. Our study thus captures for the first time a qualitative difference of an antibody response among individuals treated with fingolimod. This is particularly interesting because the concentration of anti-influenza antibodies induced by vaccination does not necessarily differ in patients with MS treated with fingolimod compared to HC. ${ }^{5}$ Limitations of our study are that the vaccination model we used does not reflect the complexity of a realworld infection and that our cohorts were not tightly matched for age. Also, our observation remains associative, and the study was neither powered nor intended to assess clinical endpoints in relation to avidity of vaccinespecific antibody responses. Irrespective of these limitations, however, the data firmly indicate that so-called protective antibody titers-a measure that lacks the dimension of quality — should be interpreted with extra care in patients with MS treated with fingolimod. 
A

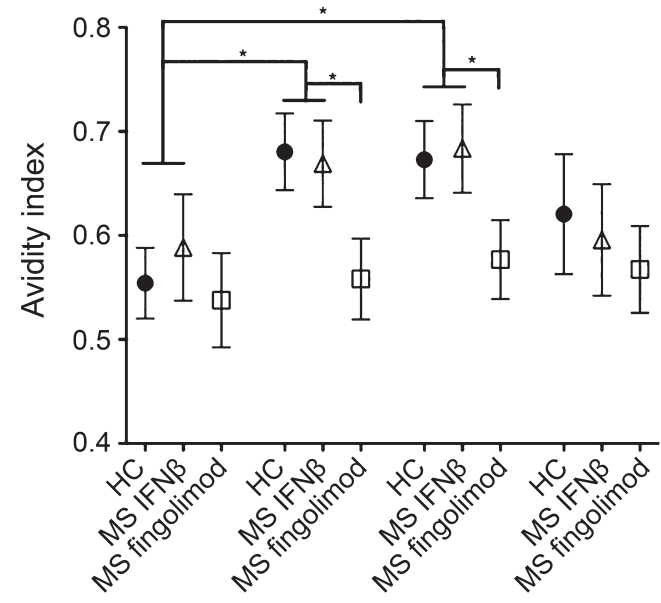

Day 0

Day 7

Day 14

Day 28

Avidity of immunoglobulin (lg) $G$ specific for influenza $A$ and $B$ before and after influenza vaccination in healthy controls $(H C)$ and in patients with multiple sclerosis (MS) treated with interferon- $\beta$ (IFN- $\beta$ ) and fingolimod. (A) Avidity index of antiinfluenza A IgG before and 7, 14, and 28 days after vaccination. (B) Avidity index of anti-influenza B IgG before and 7, 14 , and 28 days after vaccination. Mean data are shown; error bars indicate the standard error of the mean.

Although antibody avidity has not been directly linked to protective immunity in humans yet, data from human antibody adoptive transfer animal models indicate that increased avidity of vaccine-induced antibodies correlates with protective immunity. ${ }^{8,9}$ Thus, our data may help to explain the increased rate of lower respiratory tract infections observed in patients with MS treated with fingolimod. Maintaining a high level of vigilance for clinically relevant infection despite vaccination thus seems indicated when caring for patients treated with fingolimod. This study provides Class III evidence that patients with MS taking fingolimod did not significantly increase the avidity of the $\operatorname{IgG}$ antibody response targeting influenza following influenza vaccination.

* These authors contributed equally to the manuscript.

From the Immunobiology Laboratory/Department of Biomedicine and Medical Outpatient Department (M.M., D.E., G.H., C.H.) and the Department of Neurology and Clinical Neuroimmunology Laboratory/Department of Biomedicine (M.M., P.H., L.K.), University Hospital Basel, Switzerland.

Author contributions: M. Mehling, L. Kappos, and C. Hess initiated and organized the study. M. Mehling and P. Hafner organized patient-related study logistics. M. Mehling and D. Eichin performed the main experimental work. G. Hönger helped with some experimental procedures. M. Mehling and C. Hess analyzed the data and conducted statistical analysis. C. Hess supervised laboratory-related parts of the study. M. Mehling, L. Kappos, and C. Hess wrote the manuscript.

Acknowledgment: The authors thank K. Wild for excellent support with organization of study logistics.

Study funding: This investigator-initiated and sponsored study was supported by Novartis AG, Basel, Switzerland. The sponsor was not involved in designing the study, data collection, data analysis and interpretation, or writing of the report. C. Hess is supported by the Swiss National Science Foundation (310030_153059). L. Kappos and M. Mehling are supported by the Swiss MS Society.
B

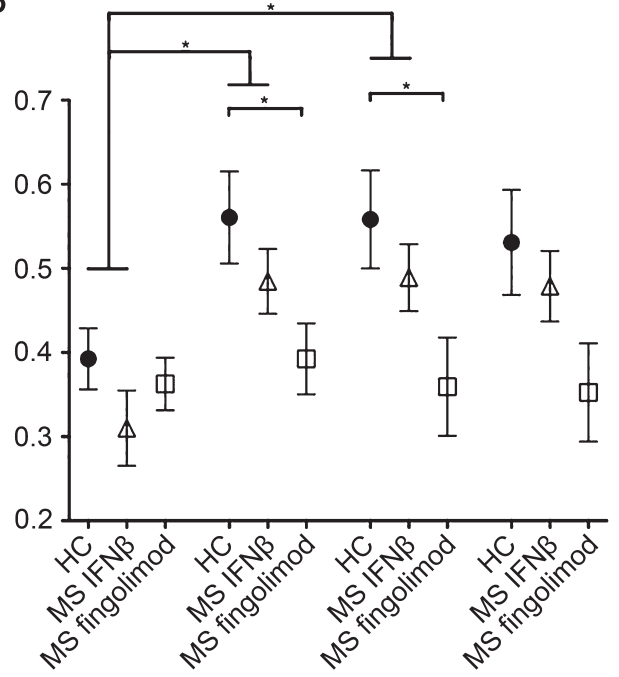

Day 0
Day 7
Day 14

Day 28
Disclosure: M. Mehling, D. Eichin, P. Hafner and G. Hönger report no disclosures. L. Kappos is on the editorial board for Multiple Sclerosis Journal, Multiple Sclerosis and Related Disorders, and Journal of Neurology; and received research support from Actelion, Addex, Bayer Health Care Pharmaceuticals, Biogen Idec, Biotica, CSL Behring, Genzyme, Lilly, Merck Serono, Mitsubishi, Novartis, Ono Pharma, Pfizer, Receptos, Roche, Sanofi-aventis, Santhera, Teva, UCB, Xenoport, the Swiss MS Society, the Swiss National Research Foundation, and the European Union. C. Hess reports no disclosures. Go to Neurology. org/nn for full disclosures. The Article Processing Charge was paid by the authors.

This is an open access article distributed under the terms of the Creative Commons Attribution-Noncommercial No Derivative 3.0 License, which permits downloading and sharing the work provided it is properly cited. The work cannot be changed in any way or used commercially.

Received February 26, 2014. Accepted in final form August 8, 2014. Correspondence to Dr.Kappos: lkappos@uhbs.chorDr.Hess: chess@ uhbs.ch

1. Kappos L, Radue EW, O'Connor PW, et al. A placebocontrolled trial of oral fingolimod in relapsing multiple sclerosis. N Engl J Med 2010;362:387-401.

2. Matloubian M, Lo CG, Cinamon G, et al. Lymphocyte egress from thymus and peripheral lymphoid organs is dependent on S1P receptor 1. Nature 2004;427:355-360.

3. Cohen JA, Barkhof F, Comi G, et al. Oral fingolimod or intramuscular interferon for relapsing multiple sclerosis. N Engl J Med 2010;362:402-415.

4. Zhang X, Wang G, Guan H, et al. FTY720 suppresses humoral immunity by inhibiting germinal center reaction. Blood 2004;104:4129-4133.

5. Mehling M, Hilbert P, Fritz S, et al. Antigen-specific adaptive immune responses in fingolimod-treated multiple sclerosis patients. Ann Neurol 2011;69:408-413. 
6. Kappos L, Arroyo R, Izquierdo G, et al. A controlled study on the effect of fingolimod (FTY720) on the immune response following seasonal influenza vaccination and tetanus toxoid booster injection in patients with multiple sclerosis. Mult Scler J 2011;17:S126.

7. Polack FP, Hoffman SJ, Crujeiras G, Griffin DE. A role for nonprotective complement-fixing antibodies with low avidity for measles virus in atypical measles. Nat Med 2003;9: 1209-1213.
8. Usinger WR, Lucas AH. Avidity as a determinant of the protective efficacy of human antibodies to pneumococcal capsular polysaccharides. Infect Immun 1999;67:23662370.

9. Romero-Steiner S, Musher DM, Cetron MS, et al. Reduction in functional antibody activity against streptococcus pneumoniae in vaccinated elderly individuals highly correlates with decreased IgG antibody avidity. Clin Infect Dis 1999;29:281-288. 


\section{Neurology \\ Neuroimmunology \& Neuroinflammation}

\section{Avidity of vaccine-induced influenza IgG fails to increase in fingolimod-treated patients with MS \\ Matthias Mehling, Dominik Eichin, Patricia Hafner, et al. \\ Neurol Neuroimmunol Neuroinflamm 2014;1; \\ DOI 10.1212/NXI.0000000000000028}

This information is current as of September 11, 2014

Updated Information \&

Services

References

Subspecialty Collections

Permissions \& Licensing

Reprints including high resolution figures, can be found at: http://nn.neurology.org/content/1/3/e28.full.html

This article cites 9 articles, 2 of which you can access for free at: http://nn.neurology.org/content/1/3/e28.full.html\#\#ref-list-1

This article, along with others on similar topics, appears in the following collection(s):

All Immunology

http://nn.neurology.org//cgi/collection/all_immunology

Multiple sclerosis

http://nn.neurology.org//cgi/collection/multiple_sclerosis

Information about reproducing this article in parts (figures,tables) or in its entirety can be found online at:

http://nn.neurology.org/misc/about.xhtml\#permissions

Information about ordering reprints can be found online: http://nn.neurology.org/misc/addir.xhtml\#reprintsus

Neurol Neuroimmunol Neuroinflamm is an official journal of the American Academy of Neurology.

Published since April 2014, it is an open-access, online-only, continuous publication journal. Copyright $($ ) 2014 American Academy of Neurology. All rights reserved. Online ISSN: 2332-7812.

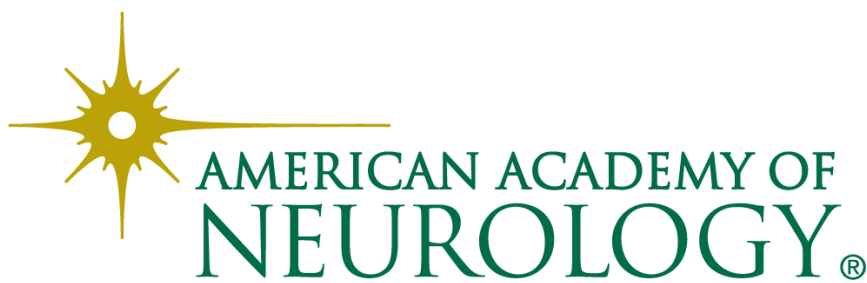

